\title{
Molecular Detection of Aflatoxin Producing Aspergillus Species Isolates in some Chicken Meat Cuts in Gharbiya Governorate, Egypt
}

\author{
Fahim Shaltout ${ }^{1, *}$, Heikal $\mathrm{Gl}^{2}$, and Ghanem $\mathrm{AM}^{3}$ \\ ${ }^{1}$ Food Hygiene and Control Dept. (Meat Hygiene), Faculty of Veterinary Medicine, Benha University, Egypt \\ ${ }^{2}$ Food Hygiene Dept, Animal Health Research Institute (Tanta branch), ARC, Egypt \\ ${ }^{3}$ Food Security Sector, Egyptian Armed Forces, Egypt
}

*Corresponding author: Fahim Shaltout, Food Hygiene and Control Dept. (Meat Hygiene), Faculty of Veterinary Medicine, Benha University, Egypt, E-mail: fahimshaltout@hotmail.com

Received: 01 Dec, 2021 | Accepted: 02 Feb, 2022 | Published: 14 Feb, 2022

Citation: Shaltout F, Heikal GI, Ghanem AM (2022) Molecular Detection of Aflatoxin Producing Aspergillus Species Isolates in some Chicken Meat Cuts in Gharbiya Governorate, Egypt. Nutr Food Technol Open Access 8(1): dx.doi.org/10.16966/2470-6086.178

Copyright: (C) 2022 Shaltout F, et al. This is an open-access article distributed under the terms of the Creative Commons Attribution License, which permits unrestricted use, distribution, and reproduction in any medium, provided the original author and source are credited.

\begin{abstract}
Contamination with fungi and their toxins is considered one of the most dangerous hidden pollutants that threaten the health of the consumer. The presence of mycotoxins in various foods has been recorded, despite their apparent safety for human consumption. The current study was conducted to evaluate the prevalence of Aspergillus species and aflatoxin producing genes using culture and molecular methods, respectively. A total of 75 samples of chicken cuts, represented by wing, breast, and thigh ( 25 of each), were randomly collected from various grocery and poultry shops located at Gharbiya governorate, Egypt. Results of culture and isolation techniques revealed the detection of Aspergillus $s p$. in 36,48 and $44 \%$ of the examined wing, breast and thigh samples, respectively. Moreover, microbiological identification of the isolated strains showed presence of $A$. niger, A. flavus, A. fumigatus, A. terreus and $A$. parasiticus in 16,13.3, 10.6, 1.3 and $1.3 \%$ of the total population of the examined samples. Molecular detection of some aflatoxin production regulating genes (OmtA, Nor1 and Ver1) in ten aspergillus sp. isolates revealed their detection in $8 / 10(80 \%), 8 / 10(80 \%)$ and $7 / 10(70 \%)$ represented by positive bands at molecular weight of 1024,400 and 537 bp, respectively. Referring to the recorded results, chicken cuts may possess a great silent hazard to human being under improper good manufacturing practices and inadequate hygienic conditions during handling and storage.
\end{abstract}

Keywords: Aspergillus species; Chicken meat cuts; CPCR; Egypt

\section{Introduction}

The production of chicken meat and its derived products in developing countries plays an essential role in supporting food security and satisfying poultry meat demand [1].

The contamination of meat products with molds can occur during different preparation stages during slaughtering under bad hygienic conditions using contaminated water or by adding contaminated spices with mold spores or during packing, handling, transportation and storage [2].

The contamination of meat with Aspergillus section flavi is one of the most hazardous microbial contaminations as most species of this section are able to produce aflatoxins that can cause severe diseases and has carcinogenic effects [3].

Acute aflatoxin poisoning may lead to death as was recorded in Kenya in 2004 [4], whereas chronic poisoning may lead to various recorded mutagens and cancers [5].

Depending on their toxigenic impacts on food and human health, aspergillus $s p$. is classified into two groups: the aflatoxigenic species such as A. flavusand A. parasiticus, and the non-aflatoxigenic strains such as A. tamarii and A. oryzae [6].
Molecular analyses have been used to confirm aflatoxin productivity of Aspergillus species isolates. omt A, nor1 and ver1 genes are from the commonly used genes encoded aflP, aflD and aflM toxins detection in food items [7] yield an accurate, rapid and reliable records of toxigenic Aspergillus species especially in food chain [8].

Therefore, the main target of the current study was to investigate the presence of toxigenic Aspergillus species in some chicken meat cuts collected from Gharbiya Governorate markets, Egypt.

\section{Materials and Methods}

\section{Collection of samples}

A total of seventy-five random samples of raw chilled chicken wing, thigh, and breast ( 25 of each) were collected from different local poultry shops and different supermarkets at Gharbia Governorate, Egypt. Samples were taken aseptically in polyethylene bags and were transferred to the laboratory in an ice box for mycological examination.

\section{Preparation of samples [9]}

Twenty-five grams from each sample were carefully and aseptically homogenized in blinder after mixing with $225 \mathrm{ml}$ of sterile peptone 
water $0.1 \%$ to form a dilution of $1: 10$, from which 10 -fold serial dilutions were prepared.

\section{Determination of Aspergillus species}

Culture of the prepared samples: Culture of the prepared samples was performed according to ISO [10], where $0.1 \mathrm{ml}$ of the previously prepared serial dilutions was spread by means of sterile L-shape glass rod over two Petri-dishes containing solidified Dichloran Rose Bengal Agar with Chloramphenicol (DRBC) were then incubated at upright position at $25^{\circ} \mathrm{C}$ for $5-7$ days.

Identification of isolated strains: Identification of isolated strains was performed according to Pitt JI, et al. [11] macroscopically and microscopically as recorded in table 1 .

\section{Molecular detection of some aflatoxin producing genes of some isolated Aspergillus strains by cPCR}

Oligonucleotide primers used in cPCR: Three pairs of omtA, nor1 and ver1 primers were prepared and collected from Metabion (Germany). Their special sequence and amplify certain products as were be displayed in table 2 .

Mycological DNA was extracted following QIAamp DNeasy Plant Mini kit Catalogue no. 69104
Preparation of master mix and thermal profile was adapted according to the manufacturer instructions (Emerald Amp GT PCR master mix (Takara) Code No. RR310A).

\section{Results}

As recorded in table 3, Aspergillus sp. was detected in 32 (42.6\%) of the total examined samples. In detail, breast samples recorded the highest contamination level (48\%); followed by thigh and wing samples, respectively.

Regarding the genus identification, $A$. niger had the highest detection levels (16\%) in the examined samples (Table 4).

Referring to the obtained results of molecular detection of some aflatoxin producing genes as recorded in table 5 and figures 1-3; omtA, nor 1 and ver 1 genes were detected in $8 / 10(80 \%), 8 / 10(80 \%)$ and $7 / 10$ (70\%) of the examined A. flavus isolates, respectively. The presence of these genes indicated the producibility of the examined strain for aflatoxins $\mathrm{P}, \mathrm{D}$ and $\mathrm{M}$, respectively.

\section{Discussion}

Chicken meat and meat products comply an important source of human protein supplement all over the world because they provide a good source of digestible protein, low cholesterol fat, essential amino acids, minerals, and different types of vitamins.

Table 1: Morphological character of aspergillus species [11]

\begin{tabular}{|c|c|c|c|c|c|c|c|c|c|}
\hline & $\begin{array}{c}\text { Colony } \\
\text { Diameter }(\mathrm{mm})\end{array}$ & Texure & Surface color & Reverse color & Stipes & Vesicles & Serriation & Conidia & $\begin{array}{l}\text { Colonial head/ } \\
\text { cleistotheca }\end{array}$ \\
\hline A. flavus & $65-70$ & $\begin{array}{c}\text { Floccose } \\
\text { powdery or } \\
\text { granular }\end{array}$ & $\begin{array}{l}\text { Greenish } \\
\text { yellow }\end{array}$ & Pale brown & Rough hyaline & $\begin{array}{l}\text { Globose or } \\
\text { subglobose }\end{array}$ & Biseriate & $\begin{array}{l}\text { Globose to } \\
\text { ellipsoid }\end{array}$ & Radiating head \\
\hline A. fumaiguts & $40-70$ & $\begin{array}{l}\text { Vevety to } \\
\text { powder }\end{array}$ & $\begin{array}{c}\text { Blue with } \\
\text { white margin }\end{array}$ & Slight green & $\begin{array}{l}\text { Smooth } \\
\text { hyaline }\end{array}$ & Clavate & Uniseriate & $\begin{array}{l}\text { Globose or } \\
\text { subglobose }\end{array}$ & Columner head \\
\hline A. nidulans & $50-65$ & Velvety & Green & Brown & Smooth brown & Pyriform & Biseriate & $\begin{array}{l}\text { Globose } \\
\text { rough }\end{array}$ & $\begin{array}{l}\text { Radiate head/ } \\
\text { hulla Cells ascs }\end{array}$ \\
\hline A. niger & $50-70$ & $\begin{array}{c}\text { Granular of } \\
\text { powdery }\end{array}$ & Black & Pale yellow & $\begin{array}{c}\text { Smooth Yellow } \\
\text { to brown }\end{array}$ & Round & Biseriate & $\begin{array}{l}\text { Globose } \\
\text { brown }\end{array}$ & Round head \\
\hline A. terus & $40-60$ & Powdery & $\begin{array}{l}\text { Sandy to } \\
\text { brown }\end{array}$ & Pale brown & $\begin{array}{l}\text { Smooth } \\
\text { hyaline }\end{array}$ & $\begin{array}{l}\text { Round to } \\
\text { pyriform }\end{array}$ & Biseriate & $\begin{array}{l}\text { Globose to } \\
\text { ellipsiod }\end{array}$ & Columner head \\
\hline
\end{tabular}

Table 2: Oligonucleotide primers sequences.

\begin{tabular}{|c|c|c|c|}
\hline Gene & Sequence (5'----3') & Amplified product (bp) & Reference \\
\hline \multirow{2}{*}{ omtA } & GGCCCGGTTCCTTGGCTCCTAAGC & \multirow{2}{*}{1024} & \multirow{6}{*}{ Norlia M, et al. 2019 [29] } \\
\hline & CGCCCCAGTGAGACCCTTCCTCG & & \\
\hline \multirow{2}{*}{ nor1 } & ACCGCTACGCCGGCACTCTCGGCAC & \multirow{2}{*}{400} & \\
\hline & GTTGGCCGCCAGCTTCGACACTCCG & & \\
\hline \multirow{2}{*}{ ver1 } & GCCGCAGGCCGCGGAGAAAGTGGT & \multirow{2}{*}{537} & \\
\hline & GGGGATATACTCCCGCGACACAGCC & & \\
\hline
\end{tabular}

Table 3: Prevalence of Aspergillus species in the examined chicken meat cut samples ( $n=25$ of each).

\begin{tabular}{|c|c|c|c|c|c|c|c|}
\hline \multirow{2}{*}{ Samples } & \multicolumn{3}{|c|}{ Wing } & \multicolumn{2}{c|}{ Breast } & \multicolumn{2}{c|}{ Thigh } \\
\cline { 2 - 7 } & No. & $\% *$ & No. & No. & $\% *$ & No. & Notal \\
\hline Aspergillus sp. & 9 & 36 & 12 & 48 & 11 & 44 \\
\hline
\end{tabular}

$\% *$ prevalence in relation to the number of each sample (25).

$\% * *$ prevalence in relation to the total number of samples population (75). 


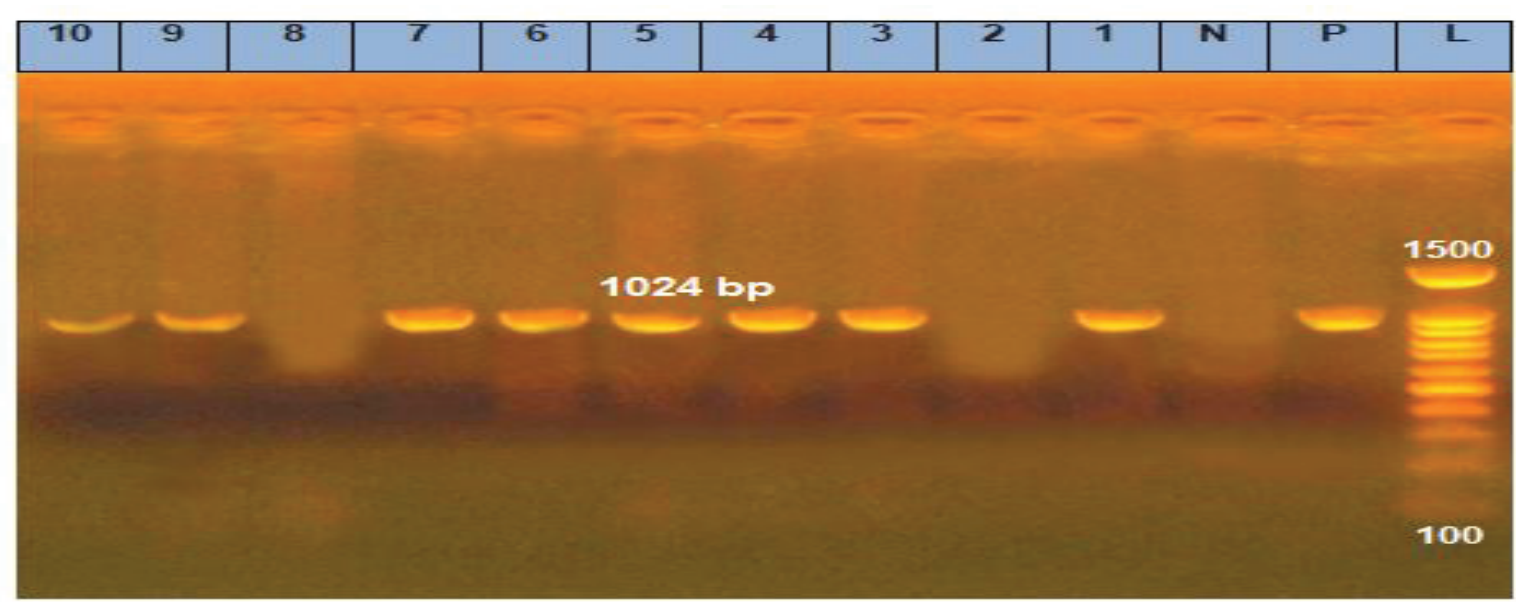

Figure 1: Agarose gel electrophoresis of cPCR of omtA (1024 bp) gene of A. flavus.

Lane L: 100 bp ladder as molecular size DNA marker.

Lane P: Control positive A. flavus for omtA gene.

Lane $\mathrm{N}$ : Control negative.

Lanes 1, 3, 4, 5, 6, 7, 9 and 10: Positive $A$. flavus for omtA gene.

Lanes 2 and 8: Negative $A$. flavus for omtA gene.

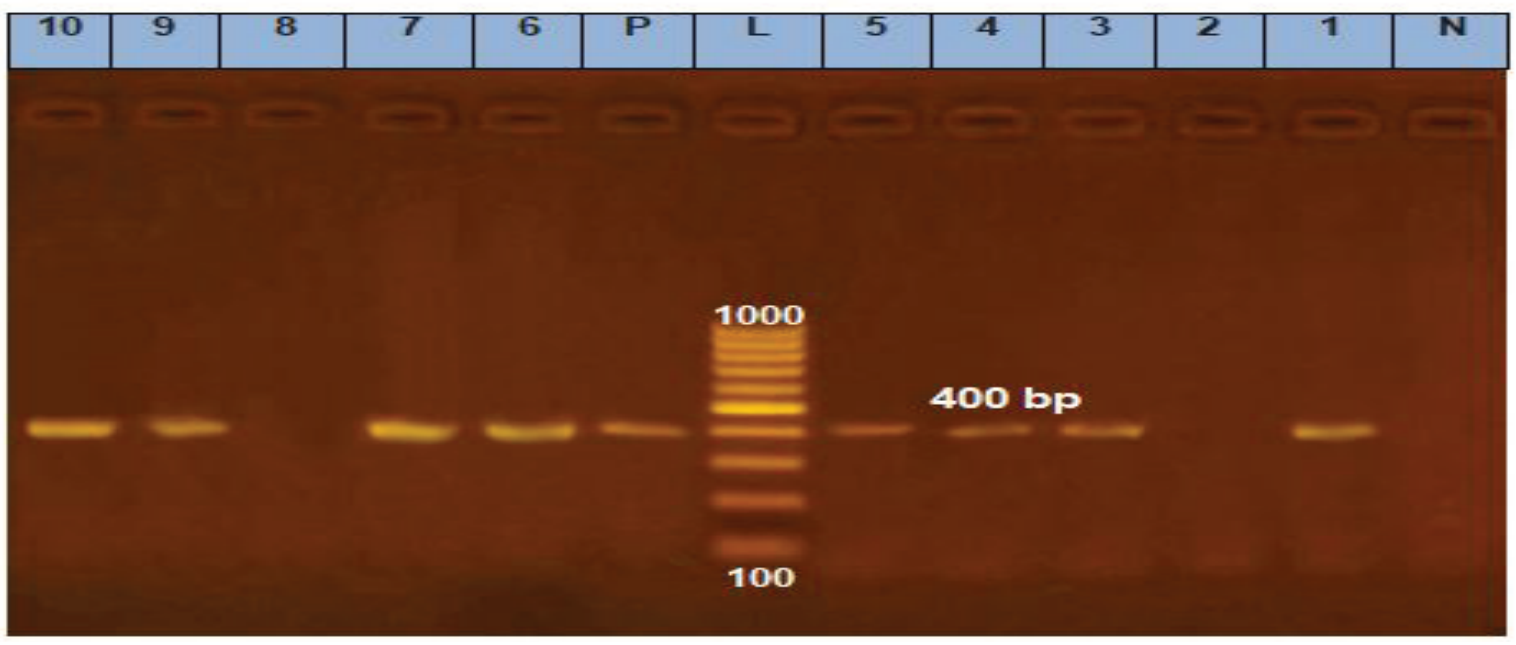

Figure 2: Agarose gel electrophoresis of cPCR of nor1 (400 bp) gene of A. flavus.

Lane L: 100 bp ladder as molecular size DNA marker.

Lane P: Control positive $A$. flavus for nor1 gene.

Lane $\mathrm{N}$ : Control negative.

Lanes 1, 3, 4, 5, 6, 7, 9 and 10: Positive $A$. flavus for nor1gene.

Lanes 2 and 8: Negative $A$. flavus for nor1 gene.

Table 4: Prevalence of identified Aspergillus spp. in the examined chicken meat cuts ( $n=25$ of each).

\begin{tabular}{|l|c|c|c|c|c|c|c|c|}
\hline \multicolumn{1}{|c|}{ Samples } & \multicolumn{2}{c|}{ wings } & \multicolumn{2}{c|}{ breast } & \multicolumn{2}{c|}{ thigh } & \multicolumn{2}{c|}{ Total } \\
\hline Aspergillus spp. & No. & $\%$ & No. & $\%$ & No. & $\%$ & No. & $\%$ \\
\hline A. niger & 4 & 16 & 6 & 24 & 2 & 8 & 12 & 16 \\
\hline A. flavus & 2 & 8 & 4 & 16 & 4 & 16 & 10 & 13.3 \\
\hline A. fumigatus & 2 & 8 & 1 & 4 & 5 & 20 & 8 & 10.6 \\
\hline A. terreus & 1 & 4 & - & & - & & 1 & 1.3 \\
\hline A. parasiticus & - & - & 1 & 4 & - & & 1 & 1.3 \\
\hline
\end{tabular}






Figure 3: Agarose gel electrophoresis of cPCR of ver1 (537 bp) gene of A. flavus.

Lane L: 100 bp ladder as molecular size DNA marker.

Lane P: Control positive $A$. flavus for ver1 gene.

Lane $\mathrm{N}$ : Control negative.

Lanes 1, 3, 4, 5, 6, 9 and 10: Positive $A$. flavus for ver1 gene.

Lanes 2, 7 and 8: Negative $A$. flavus for ver1 gene.

Table 5: Prevalence of aflatoxin producing genes in A. flavus isolates from the examined samples $(n=10)$.

\begin{tabular}{|c|c|c|c|}
\hline Sample & omtA & nor1 & ver1 \\
\hline 1 & + & + & + \\
\hline 2 & - & - & - \\
\hline 3 & + & + & + \\
\hline 4 & + & + & + \\
\hline 5 & + & + & + \\
\hline 6 & + & + & + \\
\hline 7 & + & + & - \\
\hline 8 & - & - & + \\
\hline 9 & + & + & + \\
\hline 10 & + & + & \\
\hline
\end{tabular}

In Egypt, as human population increasing, demand of animal proteins also is increasing represents a serious challenge in while poultry industry plays an essential role in filling nutrition gap as a rapid and more economic source of proteins [12].

Mold contamination of meat and meat products has been considered a serious source of food spoilage, resulting in different organoleptic changes in flavor, color, texture, odor referred mainly to fungal deterioration, especially in poor developing countries due to lack of hygienic measures during processing and handling [13].

The presence of mold in foods may be referred to the rapid, easy disperse and wide spread of fungal spores, which are abundant in the environment introducing food chain through dust, water, workers and equipment. Their presence in food samples is a serious public health concern as these fungi may be associated with the production of mycotoxins [14].

Aspergillus species represents an important mycotic infection in public health concern as a human pathogen and as toxin-producing food contaminant. It releases a lot of spores which found in air, water, soil, plant debris, manure and animal feed. As fungal spore's growing, it secretes digestive enzyme and mycotoxins leading to food spoilage and human mycotoxicosis [15].

Referring to the recorded results in table 3, Aspergillus sp. was prominently detected in breast samples other than wings and thighs samples, which came in agree with the previously recorded results of Darwish W, et al. (2016) [16] and Shaltout F, et al. (2019) [17] who found that the examined breast samples were more contaminated with fungal infection than wing and thigh samples. While the current prevalence of Aspergillus species in the examined samples came lower than those recorded by Hassan W, et al. (2019) [18] who found Aspergillus sp. in all the examined samples (100\%) collected from Gharbiya governorate, Egypt. Moreover [19] also detected A. flavus and $A$. niger in 40 and $80 \%$ of the examined sausage samples of chicken origin, respectively.

Referring to the obtained results of the microbiological identification of Aspergillus sp. isolates as recorded in table 4, they came in agree with the previously reported results by Darwish W, et al. (2016) [16] who found that $A$. niger was the predominant detected strain, followed by $A$. flavus and $A$. parasiticus in the examined samples of chicken cuts collected from Zagazig city, Egypt.

Some mold species can cause respiratory infections representing a significant risk for individual with severely weakened immune system [20]. Presence of mold in high incidence indicate bad hygienic measures adopted during handling, preparation and processing [21].

Mycotoxins are have been defined as naturally occurring secondary fungal metabolites produced in meat and meat products by direct 
growth of toxigenic molds such as Aspergillus species which produce aflatoxins and ochratoxins which threat public health due to their carcinogenic, hepatotoxic, nephrotoxic, teratogenic and mutagenic effects in humans and animals [22].

Aflatoxins are produced by a polyketide pathway that passes through about twenty-seven enzymatic reactions which have been regulated by sets of genes including nor-1, ver-1 and omtA have been shown to be involved in this process. aflD (nor-1) encodes a norsolorinic acid keto reductase needed for the conversion of the 10- keto group of Norsolorinic Acid (NOR) to the 10-hydroxyl group of Versicolorin A (VERA) [23] aflM (ver-1), predicted to encode a keto reductase, is involved in the conversion of VERA into Sterigmatocystin (ST) [24] ; aflP (omtA) codes for O-methyl transferase, which is one of the main genes responsible for transforming ST into O-methyl sterigmatocystin (OMST) that is the precursor for aflatoxin production [25].

Many other previous studies recorded the detection of these genes in their Aspergillus isolates of food origin with various PCR techniques [26-29], who conducted several studies investigating the aflatoxigenicity of Aspergillus sp. could detect different genes in their Aspergillus isolates.

\section{Conclusion}

It could be concluded that, breast samples revealed the highest contamination levels with Aspergillus sp; in addition, A. niger was the most prominently detected strain. PCR technique is a unique diagnostic tool for detection and identification of aflatoxigenic Aspergillus strains especially if the field of food safety. So, application of strict hygienic measures, proper use of water supply and food additives from good sources is recommended.

\section{References}

1. Wonga JT, Bruyna JD, Bagnolabcg B, Grieved H, Li M, et al. (2017) Small-scale poultry and food security in resource-poor settings: A review. Glob Food Sec 15: 43-52.

2. Khalalfalla FA, Ali FHM, Saif-Alnasr MM (2017) Microbiological quality of retail meats. J Vet Med Res 24: 311-321.

3. Leggieri MC, Toscano P, Battilani P (2021) Predicted Aflatoxin B 1 Increase in Europe Due to Climate Change: Actions and Reactions at Global Level. Toxins (Basel) 13: 292.

4. Probst C, Njapau H, Cotty PJ (2007) Outbreak of an acute aflatoxicosis in Kenya in 2004: identification of the causal agent. Appl Environ Microbiol 73: 2762-2764.

5. Benkerroum N (2020) Chronic and Acute Toxicities of Aflatoxins: Mechanisms of Action. Int J Environ Res Public Health 17: 423.

6. Frisvad JC, Hubka V, Ezekiel CN, Hong SB, Nováková A, et al. (2019) Taxonomy of Aspergillus section Flavi and their production of aflatoxins, ochratoxins and other mycotoxins. Stud Mycol 93: 1-63.

7. Sohrabi N, Taghizadeh M (2018) Molecular identification of aflatoxigenic Aspergillus species in feedstuff samples. Curr Med Mycol 4: 1-6.

8. Sadhasivam S, Britzi M, Zakin V, Kostyukovsky M, Trostanetsky A, et al. (2017) Rapid Detection and Identification of Mycotoxigenic Fungi and Mycotoxins in Stored Wheat Grain. Toxins (Basel) 9: 302.

9. ISO 6887-1 (2017) Microbiology of the food chain-Preparation of test samples, initial suspension and decimal dilutions for microbiological examination-Part 1: General rules for the preparation of the initial suspension and decimal dilutions.
10. ISO 21527-1 (2008) Microbiology of food and animal feeding stuffsHorizontal method for the enumeration of yeasts and moulds-Part 1: Colony count technique in products with water activity greater than 0,95 .

11. Pitt Jl, Hocking AD (2009) Fungi and Food Spoilage. $2^{\text {nd }}$ Ed, Springer, Hardcover 519.

12. Shaltout FA, Eltanani J, Zakaria I M, Elmelegy AS (2015) Microbiological status of meat and chicken received to University student hostel. Benha Vet Med J 29: 187-192.

13. Lorenzo JM, MunekataPE, Dominguez R, PateiroM, Saraiva JA, et al. (2018) Chapter 3 - Main Groups of Microorganisms of Relevance for Food Safety and Stability: General Aspects and Overall Description. Innov Technol Food Preserv 53-107.

14. Benedict K, Chiller TM, Mody RK (2016) Invasive Fungal Infections Acquired from Contaminated Food or Nutritional Supplements: A Review of the Literature. Foodborne Pathog Dis 13: 343-349.

15. Richardson M, Richardson RR (2019) Exposure to Aspergillus in Home and Healthcare Facilitie's Water Environments: Focus on Biofilms. Microorganisms 7: 7.

16. Darwish W, Bayomi RM, Moaty AAE, Gad T (2016) Mould contamination and aflatoxin residues in frozen chicken meat-cuts and giblets. Jpn J Vet Res 64: 167-171.

17. Taha B, Shaltout F, Nasief M, Lotfy L (2019) Microbiological status of chicken cuts and its products. Benha Vet Med J 37: 57-63.

18. Hassan W (2019) Some studies on effect of turmeric and lemon extracts on fungal contamination of chicken meat. Thesis, Master of Vet Med (Meat Hygiene), Benha Univ, Egypt.

19. Abuzaid KEA, Shaltoutorcid F, Salem R, Diasty EME (2020) Microbial Aspect of some processed meat products with special reference to aflatoxins. Benha Vet Med J 39: 24-28.

20. Occupational safety and Health Administration (2010) A brief guide to mold in work place. OSHA Gov California, USA.

21. El Abbasy TM (2007) Mycological aspects of quail carcasses with a trial to improve their sanitary status. Thesis Master of Vet Med (Meat Hygiene) Zagazig Univ, Egypt.

22. Agriopoulou S, Stamatelopoulou E, Varzakas T (2020) Advances in Occurrence, Importance, and Mycotoxin Control Strategies: Prevention and Detoxification in Foods. Foods 9: 137.

23. Zhou R, Linz JE (1999) Enzymatic function of the nor-1 protein in aflatoxin biosynthesis in Aspergillus parasiticus. Appl Environ Microbiol 65: 5639-5641.

24. Henry KM, Townsend CA (2005) Ordering the reductive and cytochrome P450 oxidative steps in demethylsterigmatocystin formation yields general insights into the biosynthesis of aflatoxin and related fungal metabolites. J Am Chem Soc 127: 3724-3733.

25. Yabe K, Ando Y, Hashimoto J, Hamasaki T (1989) Two distinct O-methyltransferases in aflatoxin biosynthesis. Appl Environ Microbiol 55: 2172-2177.

26. Manonmania HK, Anandb S, Chandrashekarc A, Rati ER (2005) Detection of aflatoxigenic fungi in selected food commodities by PCR. Process Biochem 40: 2859-2864.

27. Rodrigues P, Venâncio A, Kozakiewicz Z, Lima N (2009) A polyphasic approach to the identification of aflatoxigenic and non-aflatoxigenic strains of Aspergillus Section Flavi isolated from Portuguese almonds. Int J Food Microbiol 129: 187-193. 
28. Hassan MN, Nada HMS, Sayed ASAE (2015) Detection of aflatoxins by HPLC and the expression of biosynthetic nor-1 gene of aflatoxin and ocrA gene of ochratoxin. Benha Vet Med J 29: 1-10.

29. Norlia M, Jinap S, Marn K, Radu S, Samsudin NIP, et al. (2019) Aspergillus section Flavi and Aflatoxins: Occurrence, Detection, and Identification in Raw Peanuts and Peanut-Based Products Along the Supply Chain. Front Microbiol 10: 2602. 